\title{
MANAGEMENT OF ENDOCRINE DISEASE Does gender matter in the management of acromegaly?
}

\author{
Nèle F Lenders, Ann I McCormack and Ken K Y Ho
}

Garvan Institute of Medical Research; Department of Endocrinology, St Vincent's Hospital; and St Vincent's Clinical School, Faculty of Medicine, the University of New South Wales, Sydney, Australia

Correspondence should be addressed

to K K Y Ho

Email

k.ho@garvan.org.au

\begin{abstract}
Gonadal steroids modulate the effects of $\mathrm{GH}$, with oestrogens attenuating and androgens augmenting $\mathrm{GH}$ action. Whether these divergent effects influence the clinical manifestation, management and prognosis of acromegaly have not been carefully reviewed. This review examines whether there is a gender difference in epidemiology, presentation, quality of life $(\mathrm{Q} \circ \mathrm{L})$, morbidity, treatments and mortality of acromegaly. Acromegaly is more common in women who present at an older age with longer diagnostic delay. At presentation, women have a higher GH relative to IGF-1 level than men. QoL is more adversely affected in women both before and after treatment. Prevalence of hypertension and diabetes are greater in women than in men with acromegaly. Treatment outcomes with SSAs are comparable between sexes, but women may require a higher dose of pegvisomant for equivalent response. Mortality in untreated acromegaly is more profoundly affected in women; however, improved treatments in recent decades have resulted in normalisation of standard mortality ratios in both sexes. We conclude that gender does matter in the management of acromegaly, with women presenting later in life, with greater diagnostic delay, higher prevalence of comorbidities and experiencing worse QoL.
\end{abstract}

\section{Introduction}

Gender is defined by the Oxford Dictionary as the state of being male or female as expressed by social or cultural distinctions and differences, rather than a biological one. There are numerous genetic, epigenetic, environmental, social and psychological factors underlying gender identity (1). Several diseases show gender dimorphism. Autoimmune diseases occur more frequently in women than in men, a phenomenon attributable to genetic and the regulatory effects of oestrogens on the immune system (2). For pituitary disease, prolactinomas, which are the most common among functioning adenomas, occur more frequently in women than in men (3). There is strong experimental evidence for a pathogenic role of oestrogens in pituitary tumourigenesis, particularly for prolactinomas $(4,5,6)$. However, the question as to whether acromegaly is influenced by gender is not known.

\section{Invited Author's profile}

Ken Ho is Emeritus Fellow at The Garvan Institute of Medical Research and Professor of Medicine at the University of New South Wales and St. Vincent's Hospital, Sydney, Australia. Hisresearch interests include pituitary disorders, neuroendocrine regulation of substrate and energy metabolism and endocrinology of sports.

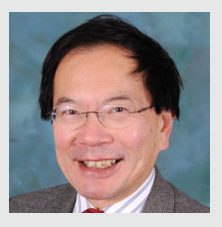


Early studies reported a mild preponderance of women among patients with acromegaly $(7,8)$. A recent large study observed that diagnosis is delayed and that IGF-I levels are lower at diagnosis in women with acromegaly (9). There are physiologicalinteractionsbetweengonadalsteroidsandtheGH axis that could influence biochemistry and symptomatology associated with acromegaly between the sexes. The clinical picture of acromegaly arises from hypersecretion of $\mathrm{GH}$, the effects of which are mediated directly or indirectly through IGF-I, causing soft tissue, musculoskeletal, cardiovascular and metabolic changes. The fluid-retaining and diabetogenic properties are direct effects of GH, while the growth promoting effects are IGF-I mediated (10). Gonadal steroids modulate the secretion and action of GH. Androgens enhance the action of GH on fluid retention and on protein anabolism (11). In contrast, estrogens exert an opposite effect by inhibiting the production of IGF-I from the liver (12). These divergent effects of androgens and oestrogens on GH action may influence the clinical picture of acromegaly in men and women.

Based on the considerations mentioned previously, this narrative review will examine whether there is a gender effect on acromegaly by critically examining the demography, biochemistry, natural history, symptomatology, morbidities, management, treatment outcomes and mortality of this disease. A literature search was conducted in Pubmed and Medline using the terms 'acromegaly' and 'gender'. Journal articles were individually reviewed for relevance, quality, size and exclusion of duplicate data.

\section{Epidemiology}

The epidemiology of acromegaly has been widely reported in large population studies, conducted in Europe, United Kingdom and Asia (Table 1). In 1980, Alexander et al. (8) reported on patients identified through treating clinicians, hospital records and death certificates. In a population of 3100000 (Newcastle, UK), 164 patients with acromegaly were identified, with $57 \%$ being female (8). This female predominance has been replicated in several $(13,14,15,16)$, but not all $(17,18,19)$ studies. A summary of the gender distribution (Table 1) reveals that of an overall total of 5955 patients, $53.9 \%$ were female. Incidence data, where available, corroborates prevalence data, with higher female incidence in some $(13,16,20)$ but not all studies (19). Burton et al. reported female incidence at 12 cases per million person-years and male incidence at ten cases per million person years (13). Gruppetta et al. reported standard incidence ratio of 0.31 per 100000 per year, with $70.6 \%$ of cases being female (16). Park et al. reported a higher incidence in females than males (4.06 per million persons vs 3.09 per million persons) (20). Conversely, Tjornstrand et al. reported equivalent incidence between male and female subjects (19).

They were all large, population-based studies performed within the constraints of different national health care systems, data collection and reporting practices, limitations in accuracy of reporting/ registering patients. These factors are likely to account for some of the conflicting observations, wherein a few studies have

Table 1 Gender distribution and prevalence of acromegaly in population studies.

\begin{tabular}{|c|c|c|c|c|c|c|c|c|c|c|}
\hline \multirow[b]{2}{*}{ Year } & \multirow[b]{2}{*}{ Author } & \multirow[b]{2}{*}{ Country } & \multirow[b]{2}{*}{ Population } & \multirow[b]{2}{*}{ Data source } & \multicolumn{3}{|c|}{ Female distribution } & \multicolumn{3}{|c|}{ Prevalence (per 100 000) } \\
\hline & & & & & Number & Females & $\%$ & Number & Males & Females \\
\hline 2016 & $\begin{array}{l}\text { Burton et al. } \\
\text { (13) }\end{array}$ & USA & 50170946 & $\begin{array}{l}\text { Insurance claims } \\
\text { data }\end{array}$ & 2241 & 1165 & 52 & 7.8 & 7.7 & 7.7 \\
\hline 2013 & Kwon et al. (14) & South Korea & 48456369 & $\begin{array}{l}\text { Secondary and } \\
\text { tertiary centres } \\
\text { of South Korea }\end{array}$ & 1350 & 743 & 55 & 2.8 & 1.3 & 1.5 \\
\hline 2004 & $\begin{array}{l}\text { Mestron et al. } \\
\text { (15) }\end{array}$ & Spain & NA & $\begin{array}{r}\text { Nationwide } \\
\text { database }\end{array}$ & 1219 & 741 & 60.8 & 3.4 & NA & NA \\
\hline 2007 & Bex et al. (18) & $\begin{array}{l}\text { Belgium, } \\
\text { Luxembourg }\end{array}$ & 10850000 & $\begin{array}{l}\text { Nationwide } \\
\text { survey }\end{array}$ & 418 & 205 & 49 & 4.1 & NA & NA \\
\hline 2016 & Dal et al. (33) & Denmark & 5534738 & $\begin{array}{r}\text { Nationwide } \\
\text { database }\end{array}$ & 405 & 190 & 47 & 8.5 & NA & NA \\
\hline 1980 & $\begin{array}{l}\text { Alexander et al. } \\
\text { (8) }\end{array}$ & UK & 3100000 & Regional data & 164 & 93 & 57 & 4 & NA & NA \\
\hline 2014 & $\begin{array}{l}\text { Tjornstrand } \\
\text { et al. (19) }\end{array}$ & Sweden & 1590640 & $\begin{array}{l}\text { Nationwide } \\
\text { registry }\end{array}$ & 53 & 26 & 49 & 3.3 & 1.7 & 1.6 \\
\hline 2015 & $\begin{array}{l}\text { Agustsson et al. } \\
\text { (17) }\end{array}$ & Iceland & 330000 & $\begin{array}{l}\text { National Health } \\
\text { Service }\end{array}$ & 53 & 21 & 39.6 & 13.7 & NA & NA \\
\hline \multirow[t]{2}{*}{2013} & $\begin{array}{l}\text { Gruppetta et al. } \\
\text { (16) }\end{array}$ & Malta & 417608 & $\begin{array}{l}\text { Central hospital } \\
\text { registry }\end{array}$ & 52 & 30 & 57.7 & 12.4 & 10.6 & 14.3 \\
\hline & & & Total & & 5955 & 3215 & 53.9 & & & \\
\hline
\end{tabular}


not observed a higher prevalence in women. Nevertheless, the collective data reveal evidence that acromegaly affects more women than men.

\section{Age at diagnosis}

Numerous population and registry studies have reported on age at diagnosis with acromegaly, results of which are summarised in Fig. 1 (9, 14, 16, 17, 18, 21, 22, 23, $24,25,26,27,28,29,30)$. Of the 15 studies surveyed, ten reported that men were significantly younger than women at diagnosis, by a median of 4.5 years (total $n=10$ 372 , range 1.8-6.6 years) $(9,14,21,22,24,25,26,27$, $28,30)$. Other studies demonstrated a trend towards younger diagnosis in men than women, without reaching statistical significance (total $n=1763)(16,17,18,23,29)$. The difference in age at diagnosis is highly consistent between studies providing compelling evidence for a true gender dimorphism.

\section{Diagnostic delay}

The question as to whether a later age of diagnosis in women may be due to a delay in diagnosis has been investigated in a number of studies (Table 2). In the Liege Acromegaly Database ( $n=3143)$, Petrossians et al. (9) reported that female patients had a median delay to diagnosis of 2 years longer than their male counterparts. Additionally, female patients consulted a higher number of physicians before achieving diagnosis (9). Similarly, data from the Swedish National Patient registry $(n=135)$ demonstrated that median time to diagnosis was 4.6 years earlier in men than in women (31).

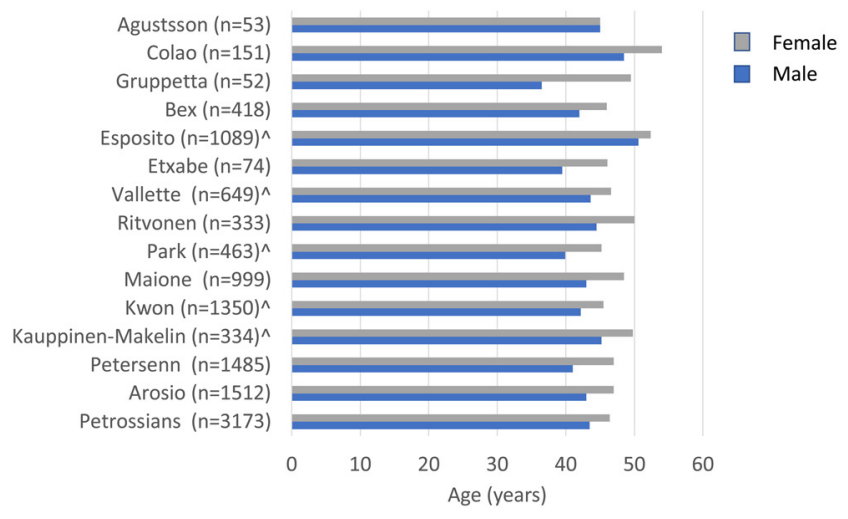

\section{Figure 1}

Median age at diagnosis of acromegaly in males and females from 15 international studies.
In the only study to specifically evaluate gender discrepancy in diagnostic evaluation of acromegaly, KreitschmannAndermahr et al. $(n=165)$ found that women waited 2.5 years longer than men for correct diagnosis and consulted more doctors (4.0 vs 2.7) (32). The authors proposed that early symptomatology of acromegaly may be erroneously attributed to menopausal symptoms. In contrast to the previously mentioned studies, a large German registry study $(n=1485)$ reported 1 year longer time to diagnosis in men than in women (22). Dimorphism in clinical presentation has not otherwise been widely investigated in large population and registry studies $(8,13,14,15,16,17,18,19,23,24,25$, $26,27,28,29,30,33)$. Evidence supports diagnostic delay in women with acromegaly compared with men.

\section{Biochemistry at diagnosis}

GH secretion and action are modulated by gonadal steroids (10). In normal subjects, testosterone enhances $\mathrm{GH}$ secretion $(11,34)$ and responsiveness $(10,35,36$, $37,38,39)$. By contrast, oestrogens attenuate $\mathrm{GH}$ action reducing IGF-1 production (10). These regulatory effects of sex steroids result in women having higher levels of GH than men but with similar levels of IGF-I $(12,40,41)$.

In acromegaly, sex steroids affect GH-IGF-1 relationship in a similar way. In a study of 76 patients with acromegaly, Tanaka et al. (42) observed the mean IGF-I concentration and IGF-1/GH ratio to be significantly lower in women than in men despite both genders having similar mean GH concentrations. When stratified to age groups below and over 50 years, the gender difference in IGF-I was significant only among the younger patients. In a recent single-centre retrospective evaluation of 463 surgically treated acromegalic patients, Park et al. (26) reported similar gender dimorphism in biochemistry. The mean preoperative IGF-1 in women was 15\% lower than in men, despite similar GH levels. This effect was present in the pre-menopausal but not in the post-menopausal age group. Parkinson et al. (43) reported on 60 patients with acromegaly with varying degree of control. A linear relationship between GH and IGF-1 was observed, with female patients having consistently lower levels of IGF-1 for a given $\mathrm{GH}$ concentration. Several epidemiological studies (total $n=1906$ ) have provided further evidence for gender dimorphism in biochemistry at diagnosis, reporting lower IGF-1 in women, despite similar GH levels between genders $(14,29,33)$. In a large German Registry ( $n=1485)$, both GH and IGF-1 were observed to be lower in women compared with their male counterparts. 
Table 2 Delay in the diagnosis of acromegaly in males and females.

\begin{tabular}{ll}
\hline Year & Author \\
\hline 2017 & Petrossians et al. (9) \\
2012 & Arosio et al. (21) \\
2009 & $\begin{array}{l}\text { Petersenn et al. (22) } \\
2016\end{array}$ Kreitschmann-Andermahr et al. (32) \\
2018 & Granfeldt (31) \\
^Mean. &
\end{tabular}

\begin{tabular}{l}
\hline Country \\
\hline Belgium, Bulgaria, France, \\
Netherlands, Italy, Sweden, \\
Czech Republic, Germany, \\
Portugal, Spain \\
Italy \\
Germany \\
Germany \\
Sweden
\end{tabular}

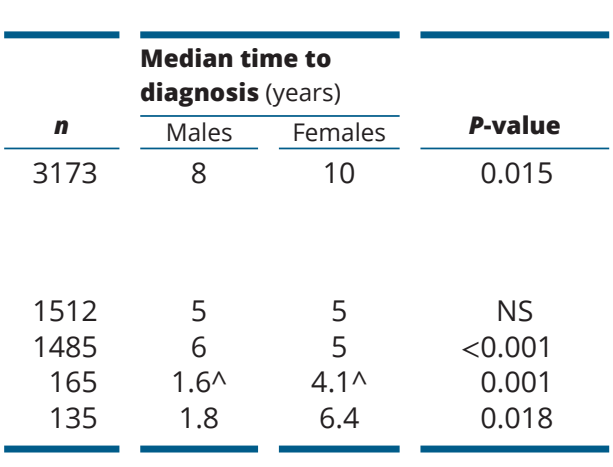

In summary, there is strong evidence for a gender effect on the biochemistry of acromegaly, characterised by a lower IGF-I in women for equivalent GH status, likely explained by an attenuating effect of oestrogens on the action of GH.

\section{Tumour size}

Tumour size at presentation has important implications for treatment efficacy and outcomes, with larger, more invasive tumours associated with worse prognosis $(18,33)$. Several studies have found that women presented with significantly larger and more invasive tumours than men. Park et al. (26) observed that women had significantly larger tumours than men and a higher proportion of tumours with cavernous sinus invasion (29.2\% vs 20.2\%). Similarly, Colao et al. (29) reported significantly larger tumours in women than in men within the younger age group (age $<40$ years). By contrast, in a large multicentre registry study, Petrossians et al. (9) observed that men had significantly larger tumours than women at diagnosis. In this study, tumour size was inversely proportional to age and larger tumours were not observed in patients older than 30 years. However, several studies have not found a significant difference in tumour size between genders $(16,17,22,24,27,33)$. A plausible explanation for gender dimorphism in tumour size is delay to diagnosis in women arising from oestrogen modulation of the GH/IGF-1 pathway (26). However, further studies are required to investigate the interaction between patient age, gender and tumour size in acromegaly.

\section{Quality of Life (QOL)}

Pituitary disease impairs quality of life, with a greater negative impact in female patients (44). The question as to whether this is the case for acromegaly has been addressed in a number of studies, summarised in Table 3. Contributors to reduced QoL in acromegaly include physical, psychological, aesthetic, social, demographic and treatment factors (45). There are three longitudinal studies that have reported the impact of gender in QoL in active acromegaly. Webb et al. (46) evaluated 106 patients with acromegaly, of which 42 had active disease. Females had worse QoL scores on all aspects of assessment, particularly mental and physical scores. Similarly, Vandeva et al. (47) preformed a cross-sectional longitudinal study of 212 patients with acromegaly over a 6-year period. Female gender was a negative predictor on all aspects of QoL scores, except for appearance. By contrast, in a longitudinal study of 41 patients who underwent successful surgery for acromegaly, Fujio et al. (48) reported no gender differences in QoL scores in active disease.

The previously mentioned longitudinal studies also evaluated QoL in disease remission and observed persistence of patterns following cure $(46,47,48)$. Several other studies have investigated QoL in patients with acromegaly in remission. Psaras et al. (49) demonstrated that in men persistent joint complaints had the largest effect on QOL, whereas in women, persistence of hypertension posed a significant perceived threat to health. In a longitudinal study of patients with treated acromegaly, Van der Klauww et al. (50) observed that women had more impairment in role functioning due to emotional problems and perceived health over time. Biermasz et al. (51) evaluated QoL in 118 subjects with successfully treated acromegaly, observing no significant difference between genders.

There are several studies that have investigated QoL in mixed cohorts of patients at various stages of treatment. Anagnostis et al. performed a case control study of 40 patients, of which $62.5 \%$ were in remission, demonstrating that female gender was a negative predictor 
Table 3 Gender and Quality of Life assessments in acromegaly.

\begin{tabular}{|c|c|c|c|c|c|c|c|}
\hline Year & Reference & Country & Study & $n$ & Assessment tool & $\begin{array}{l}\text { Disease } \\
\text { activity }\end{array}$ & $\begin{array}{l}\text { Gender } \\
\text { effect }\end{array}$ \\
\hline \multicolumn{8}{|c|}{$\overline{\text { Longitudinal studies }}$} \\
\hline 2006 & Webb et al. (46) & Spain & $\begin{array}{l}\text { Case-control, } \\
\text { longitudinal }\end{array}$ & 106 & EuroQoL, AcroQoL* & $\begin{array}{l}\text { Active disease } \\
\text { Remission }\end{array}$ & $\begin{array}{l}F>M \\
F>M\end{array}$ \\
\hline 2015 & Vandeva et al. (47) & Bulgaria & $\begin{array}{l}\text { Cohort, } \\
\quad \text { longitudinal }\end{array}$ & 212 & AcroQoL* & $\begin{array}{l}\text { Active disease } \\
\text { Remission }\end{array}$ & $\begin{array}{l}F>M \\
F>M\end{array}$ \\
\hline 2017 & Fujio et al. (48) & Japan & $\begin{array}{l}\text { Cohort, } \\
\text { longitudinal }\end{array}$ & 41 & SF-36 & $\begin{array}{l}\text { Active disease } \\
\text { Remission }\end{array}$ & $\begin{array}{l}\mathrm{Nil} \\
\mathrm{Nil}\end{array}$ \\
\hline 2008 & $\begin{array}{l}\text { Van der Klauww } \\
\text { et al. (50) }\end{array}$ & The Netherlands & $\begin{array}{l}\text { Cohort, } \\
\quad \text { longitudinal }\end{array}$ & 82 & $\begin{array}{l}\text { HADS, NHP, AcroQoL*, } \\
\text { MFI-20, SF-36 }\end{array}$ & Remission & $\mathrm{F}>\mathrm{M}$ \\
\hline 2019 & Tseng et al. (56) & Taiwan & $\begin{array}{l}\text { Cohort, } \\
\text { longitudinal }\end{array}$ & 272 & AcroQoL* & Mixed & Nil \\
\hline \multicolumn{8}{|c|}{ Cross-sectional and case-control studies } \\
\hline 2004 & Biermasz et al. (51) & The Netherlands & Case-control & 118 & $\begin{array}{l}\text { SF-36, MFI-20, NHP, } \\
\text { AcroQoL*, HADS }\end{array}$ & Remission & Nil \\
\hline 2011 & Psaras et al. (49) & Germany & Cohort & 55 & $\begin{array}{l}\text { AcroQoL*, ACCQ* } \\
\text { SF-36 }\end{array}$ & Remission & $\mathrm{F}>\mathrm{M}$ \\
\hline 2005 & Rowles et al. (54) & Spain & Cohort & 80 & $\begin{array}{l}\text { AcroQoL* }{ }^{*} \text { EuroQoL, } \\
\text { PGWB, SSS* }\end{array}$ & Mixed & Nil \\
\hline 2006 & $\begin{array}{l}\text { Kauppinen-Makelin } \\
\text { et al. (27) }\end{array}$ & Finland & Cohort & 231 & $15 D$ & Mixed & Nil \\
\hline 2007 & T'Sjoen et al. (53) & Belgium & Cohort & 291 & AcroQoL* & Mixed & $\mathrm{F}>\mathrm{M}$ \\
\hline 2013 & Kepicoglu et al. (55) & Turkey & Cohort & 133 & AcroQoL* & Mixed & $\mathrm{Nil}$ \\
\hline 2014 & Anagnostis et al. (52) & Greece & Case-control & 40 & AcroQoL*, POMS & Mixed & $\mathrm{F}>\mathrm{M}$ \\
\hline
\end{tabular}

of QoL scores, particularly in physical appearance, mood and relationship scores (52). In a Belgian nationwide cohort study with patients with varying levels of disease activity, male gender was associated with significantly worse QoL scores (53). Several other studies, reporting on patients at varying stages of disease activity, have observed no significant difference in QoL between genders $(27,54$, $55,56)$.

In summary, numerous studies examining QoL in acromegaly, heterogenous methods, assessment tools and patient cohorts have yielded mixed results, precluding clear conclusions. However, there is nonetheless some evidence that QoL appear to be poorer in females in acromegaly.

\section{Morbidity}

\section{Cardiovascular risk}

Cardiovascular risk is increased in patients with acromegaly, contributing to enhanced mortality (57 58, 59). Hypertension and diabetes are among the best studied CV risk factors in acromegaly. When compared with the general population, prevalence of diabetes and hypertension are elevated in acromegalic patients (60) and reduced after successful disease control or cure $(59,61)$. There is a clear gender dimorphism in cardiovascular disease in the general population, with a strong male predominance (62). There are limited data regarding gender distribution in cardiovascular risk in acromegaly, from studies in largely heterogenous patient groups, with controlled and uncontrolled disease.

\section{Hypertension}

In a retrospective, comparative study from Germany, 133 patients with acromegaly were compared with 665 matched controls from the general population (59). Patients with acromegaly had significantly higher prevalence of hypertension than their age and gendermatched controls. Women, but not men, had significantly higherFramingham RiskScoresthan theirmatchedcontrols. In a large Mexican registry study $(n=2057)$, the prevalence of hypertension was significantly higher in women compared with men (32\% vs 24\%) (63). Another large registry from Italy $(n=1512)$ reported a similar trend, (33.7 vs $28.7 \%$ ), which did not reach statistical significance (21). By contrast, Gonzalez et al. reported that, although successful treatment reduced blood pressure, hypertension persisted in some patients without a gender difference (60). Overall, evidence from retrospective studies suggests a 
higher prevalence of hypertension among women with acromegaly, which is opposite to that of the general population (64).

\section{Diabetes}

Type 2 diabetes is one of the most common comorbidities in acromegaly and is a major contributor to cardiovascular risk (65). Insulin resistance develops as a direct consequence of the action of GH. As GH levels are higher in women for comparable IGF-I status, it is conceivable that women may be at more risk of diabetes compared to men. Gender differences in diabetes in acromegaly are infrequently reported in epidemiological studies (Table 4). In a large Mexican multi-centre registry study of over 2000 patients, the prevalence of diabetes was nearly 50\% higher in females (30.4 vs 21.6\%) (63); however, mean GH levels were slightly higher in males. In a later outcome evaluation in 522 patients after various modes of treatment in this cohort, Gonzalez et al. (60) observed the prevalence of diabetes remained higher in women but did not comment on comparative $\mathrm{GH}$ concentrations. In a Danish population study of 405 patients, the prevalence of diabetes was higher in women (HR 6.2 vs 2) but higher GH concentrations were observed in men (33). A multicentre study of 649 patients from Canada observed no difference in the prevalence of diabetes between genders, but did not provide corresponding GH data (17). In a large Italian registry study of 1512 patients, the diabetes was associated with male gender and IGF-1, but not GH, on multivariate analysis (21). However, a detailed metabolic study of over 300 patients from one of the participating centres reported that women had higher fasting insulin levels, higher visceral adiposity levels, lower insulin sensitivity index, lower HDL cholesterol and a higher prevalence of metabolic syndrome (66). The prevalence of diabetes was more than two-fold higher in women (51 vs 19\%) despite mean GH levels being higher in men (31 vs $26 \mathrm{ug} / \mathrm{L}$ ). This study highlights the power of single centre studies employing a range of interrelated investigations to focus on specific measures of interest not possible from heterogeneous large multicentre or registry studies. A recent nationwide population-based cohort study from Korea has reported a higher prevalence of diabetes in females (57 vs 51\%) with acromegaly from insurance claims data (20). In summary, data from epidemiological and registry studies are conflicting, while evidence from a single-centre undertaking focussed metabolic investigations and from a nationwide claims database observed a higher female prevalence of diabetes. Further, careful studies are required to determine whether diabetes affects more females than males with acromegaly.

\section{Sleep disordered breathing}

Sleep disordered breathing (SDB) is common in patients with acromegaly (33). GH excess affects the structure and function of the respiratory apparatus, resulting in macroglossia, pharyngeal soft tissue hypertrophy and abnormalities of the pharynx lumen (67). The prevalence of obstructive sleep apnoea (OSA) in the general population is reported at 9-38\% with a male predominance (13-33\% vs 6-19\%) (68). Wide variation in reported prevalence stems from significant methodological heterogeneity in OSA epidemiological studies. In patients with active acromegaly, prospective polysomnography studies report prevalence of OSA ranging from 44 to $87 \%(69,70,71,72,73,74,75,76$, 77, 78, 79). SDB diminishes QoL and increases morbidity and mortality (80). Gender dimorphism observed in the general population appears to be preserved in acromegaly, although data are sparse, from small heterogenous studies $(33,70,72,75,81,82)$. In summary, studies on gender differences in the severity and prevalence of SDB in acromegaly are scant and insufficient to ascertain whether they are different from that in the general population.

\section{Malignancy}

GH stimulates cellular growth and proliferation, raising concern for increased risk of cancer in patients with acromegaly (83). This has been the subject of some

Table 4 Gender differences in the prevalence or risk of diabetes in acromegaly.

\begin{tabular}{|c|c|c|c|c|c|c|c|}
\hline Year & Reference & Country & Study & $n$ & Measure & Female & Male \\
\hline 2016 & Portocarrero-Ortiz et al. (63) & Mexico & Cohort & 2057 & Prevalence (\%) & 30.4 & 21.6 \\
\hline 2012 & Arosio et al. (21) & Italy & Cohort & 1512 & Prevalence (\%) & 12.4 & 16.2 \\
\hline 2013 & Vallette et al. (25) & Canada & Cohort & 649 & & $\sim$ & $\sim$ \\
\hline 2018 & Gonzalez et al. (60) & Mexico & Cohort, longitudinal & $522^{*}$ & HR (female) & 1.5 & \\
\hline 2016 & Dal et al. (33) & Denmark & Cohort & 405 & $\begin{array}{l}\text { Rates (per } 1000 \\
\text { person years) }\end{array}$ & 16.1 & 8.9 \\
\hline 2013 & Ciresi et al. (66) & Italy & Cohort, longitudinal & $307^{*}$ & Prevalence (\%) & 17.3 & 5.1 \\
\hline
\end{tabular}


debate in the literature, and a recent meta-analysis has demonstrated a slightly increased overall risk of cancer with acromegaly (84). Gender data are overall limited, although sex distribution from the same meta-analysis was approximately equal. Some studies reporting female preponderance $(20,85)$, some male preponderance (86) and others reporting no difference $(24,87)$. Thyroid cancers have a five-fold increased risk when compared with sex and age-matched controls (88), although surveillance bias cannot be excluded (84) because of female predominance of thyroid malignancies in the general population. Increased risk of colorectal cancer has been demonstrated in multiple studies, without gender dimorphism (89). Breast cancers are significantly more common in the women with acromegaly (5\%) compared with the general population, although study numbers are small $(88,90)$. In summary, data regarding gender dimorphism in malignancy with acromegaly are scant. Larger studies are required for clinically meaningful conclusions to be drawn.

\section{Bone health}

GH and IGF-1 regulate bone growth and remodelling, promoting differentiation of osteoblasts and chondroblasts, osteoprotegerin production and bone turnover $(91,92,93)$. The effects of these factors on bone mineral density are debated in the literature. Some data have demonstrated increased bone mineral density $(94,95)$, some decreased bone density $(95,96)$ and others unchanged bone density $(97,98,99)$. Differential sex steroid modulation of these factors may be expected to result in gender dimorphism in bone health; however, data are limited and inconclusive. Several studies have shown increased prevalence of vertebral fractures in acromegaly, independent of bone mineral density, bone turnover and disease control $(100,101,102,103)$. Male predominance has been reported, albeit particularly in the presence of concomitant hypogonadism (101). Overall, there is insufficient evidence to ascertain whether there is a gender dimorphism in acromegalic bone disease.

\section{Outcomes of treatment}

As discussed, gender influences the relationship between GH and IGF-I across a broad spectrum of GH levels. Relative resistance to the effects of $\mathrm{GH}$ with regard to IGF-I response occurs in healthy women and in women with GHD. Along with the aforementioned differences in presentation, it is possible that gender may also influence treatment outcomes in acromegaly.

\section{Surgery}

Surgery is the mainstay of therapy for acromegaly. Reported surgical cure rates are higher for microadenomas (75-90\%) than macroadenomas (45$70 \%)$, with surgical expertise being a very significant determinant of outcomes (104). There are several factors that lower probability of surgical cure: younger age at diagnosis, larger tumour volume, cavernous or sphenoid sinus invasion and sparsely granulated subtype (105). A number of studies have investigated whether gender influences these factors and in turn surgical outcomes. Park et al. (26) performed a large retrospective study of 463 patients who underwent transsphenoidal surgery with a single operating neurosurgeon in a tertiary referral centre in South Korea. Women had lower pre-operative IGF-1, larger tumours, higher proportion of cavernous sinus invasion and were older at surgery. In particular, premenopausal women had larger and more aggressive tumours than men and post-menopausal women. Total tumour resection rate was significantly lower in women than in men $85.5 \%$ vs $92.6 \%)$ as was long-term surgical remission $(76.5 \%$ vs $89.7 \%$ ) (26). By contrast, several smaller retrospective studies have reported no gender difference in surgical remission rates $(106,107,108,109,110)$. Jane et al. (106) reported that gender did not influence outcome in a retrospective single centre retrospective study of 60 patients. In another retrospective single centre study of 55 patients, Babu et al. (109) also observed that gender did not affect cure rates. Similar observation was made by Hazer et al. (108) in 214 patients and by Antunes et al. (107) in 69 patients. These studies were retrospective, heterogenous in patient groups, follow-up period and definition of cure. Several other recent studies have investigated surgical outcomes in acromegaly, without reporting specifically on gender as a predictor $(111,112,113)$. In summary, data regarding gender differences in acromegaly surgical outcomes are conflicting. The single largest study investigating this directly suggests more aggressive natural history and hence worse treatment outcomes in premenopausal women (26). Further prospective age-matched data are required to elucidate whether surgical outcomes are influenced by gender. 


\section{Medical therapy}

\section{Somatostatin Analogues (SSAs)}

Somatostatin analogues (SSAs) form the cornerstone of medical therapy in acromegaly. Many large clinical trials have demonstrated the comparable efficacy of first generation SSAs, octreotide and lanreotide, with normalisation of IGF-1 in 38-85\% and reduction of $\mathrm{GH}$ to $<2.5 \mathrm{mcg} / \mathrm{L}$ in $33-75 \%(114,115,116)$. Second generation SSA, pasireotide LAR, is associated with higher rates of biochemical cure than those achieved with octreotide (117). Nevertheless, rates of cure with SSA therapy are sub-optimal, with response affected by patient selection, compliance, baseline IGF-1 levels, prior therapy and possibly gender. In a review of SSA resistance, Cuevos-Ramos \& Fleseriu (118) proposed female gender as a positive predictor of response to SSA, attributed to oestrogen upregulation of SSTR2. However, the potential role of sex has not widely been reported in clinical trials to substantiate this. Results that are available are conflicting and inconclusive. In a large randomised, placebocontrolled multicentre study, Melmed et al. (119) reported on 99 unselected patients with acromegaly. Treatment was with Lanreotide Autogel or placebo, with 52 weeks open extension. In this study, $54.4 \%$ of females and $48 \%$ of males achieved GH defined biochemical control; 59.6\% of females and $56 \%$ of males normalised IGF- 1 . By combined criteria, $45.6 \%$ of females and $36 \%$ of males achieved biochemical cure. By contrast, in a prospective study of 104 patients treated preoperatively with lanreotide SR, normalisation of IGF-1 was reported in $25 \%$ of patients, with no gender dimorphism (120). Many other prospective studies have investigated treatment efficacy of lanreotide (seven large recent studies reviewed, total $n=2275)$, without reporting on gender data $(121,122,123,124,125,126,127)$. Results are similarly limited for octreotide. In a large multi-centre prospective trial published in 1991, 189 patients with acromegaly were treated with octreotide (128). There was no gender difference in biochemical control following treatment. Similarly, a retrospective evaluation of 110 acromegalic patients treated with octreotide LAR for 4 years demonstrated no gender difference in outcomes (129). Numerous other studies have investigated treatment efficacy of octreotide, without reporting on gender data (six large recent studies reviewed, total $n=1348$ ) (117, $130,131,132,133)$. Although a number of studies have investigated the efficacy of pasireotide, gender specific outcomes have not been reported $(117,134,135,136$, $137,138,139)$. In summary, although there are proposed mechanistic reasons for better efficacy of SSA in female patients, study data are conflicting. Further prospective trials should report on gender specific outcomes. Such data may help guide medication selection and titration in the future.

\section{$G H$ receptor antagonist}

Pegvisomant, formulated from the pegylation of a $\mathrm{GH}$ analogue which binds to but not activate the $\mathrm{GH}$ receptor, has an established place in the drug management of acromegaly (115). From the principles of competitive inhibition, biochemical control is dependent on the dose and the prevailing concentration of $\mathrm{GH}$ in blood. Biochemical control rates vary from 60 to $90 \%$, with lower rates reported in real-world studies, at least partly explained by lesser dose titration in the community than in clinical trials (115). There has been interest in identifying other factors determining the efficacy of pegvisomant, including that of gender.

Parkinson et al. (140) analysed the treatment effects between men and women in a multicentre, open-label trial of pegvisomant monotherapy in 118 patients. At baseline, mean GH levels were similar but IGF-I levels were higher in men. During treatment, there was a greater decline in IGF-1 in men, with both sexes attaining a similar level of IGF-1. Women received 20\% higher weight-corrected dose of pegvisomant than in men to achieve the same concentration, indicating that the pharmacokinetics were different. In women, for an equivalent concentration of pegvisomant, the reduction in IGF-I was lower, indicating that clearance and sensitivity were lower in women. Biochemistry was measured in a centralised laboratory. In a retrospective, multicentre cross-sectional study, Marazuela et al. evaluated the effect of gender on pegvisomant monotherapy efficacy in a smaller group of 44 patients resistant to other treatment modalities (141). Male patients had significantly greater decline in their IGF-1 from baseline than did women. More male patients were controlled at the end of treatment than were women. The mean dose of pegvisomant was significantly higher in women than in men, although significance was lost when corrected for weight. The findings are broadly similar to the those of Parkinson et al. (140). Limitations of this study were its small sample size and de-centralised laboratory studies. Franck et al. (142) reported on a multivariable regression analysis of two retrospective cohorts developing a predictive model for pegvisomant dosing, as monotherapy $(n=83)$ and in combination with long-acting SSA $(n=76)$. Sex 
differences in pegvisomant dosing were not confirmed in this larger study. The weaknesses of this study were the magnitude of missing data (72 in the monotherapy group and 65 in the combination group), and unlike the Parkinson study, GH was measured using different assays by different participating centres. In summary, there is limited though conflicting evidence suggesting that women require more pegvisomant than men for disease control.

\section{Radiotherapy}

Radiation therapy is generally considered as a third-line treatment in patients who have not achieved control with surgery and/or medical therapy. Mildly better biochemical remission and lesser adverse events are observed with stereotactic radiosurgery (SRS) than with conventional fractionated radiotherapy (RT) $(104,143)$. Nevertheless, the rates of biochemical remission with SRS are widely varied in the literature. Whether the response to radiotherapy is influenced by gender has been investigated in several studies. In a multicentre retrospective cohort, comprising of ten participating institutions, the outcome SRS in 373 patients followed for 79 months was not different between men and women (144). Another large retrospective multicentre study comprising of 14 participating centres, with 884 patients with acromegaly observed no effect of gender on the efficacy of conventional RT (145). Several further large retrospective single-centre studies have similarly observed no effect of gender on outcomes with SRS and conventional RT (total $n=367)(146,147,148)$. Conversely, in a smaller retrospective single centre review of 40 patients, Poon et al. (149) evaluated factors that may predict remission of acromegaly following gamma knife surgery. Female gender and cavernous sinus invasion were identified as failed predictors, although it is unclear if these were independent of one another. In summary, there is no substantial and consistent evidence to suggest that gender does affect remission of disease following radiation therapy.

\section{Prognosis}

Studies from the United Kingdom in the 1970-80s observed mortality rates of up to three-fold higher than the background population $(8,150,151)$. The mortality rate was higher in women in one study (151), in men in another study (8) and not different in the third (150). All three studies reported that cerebrovascular disease was the major cause of death in females, while $\mathrm{CV}$ disease and cancer also contributed to death in men. Other studies have not signalled a gender difference in increased mortality risk $(30,152)$.

Improvements in disease control brought about by more effective therapies have resulted in a gradual reduction in mortality. Recent studies from France (24), Italy (21) and Mexico (153) have reported that mortality rates in acromegaly are similar to those of the general population. In the French study, this occurred in parallel with progressive improvements in treatment and resultant disease control over a 30-year period of observation. In the Italian study, restoration of life expectancy from improved GH control was similar between males and females (21). Registry studies from the three Scandinavian countries have also reported that a decline of mortality rates in acromegaly but not to those (SMR: 1.3-2.7) of matched populations $(23,28,33)$. In Denmark, the mortality rate was similar between males and females (33). There was a two-fold higher risk of diabetes and hypertension in women and the major cause of death was cardiovascular disease for both sexes. In Sweden, cardiovascular disease was also the major cause of death with ischaemic heart disease occurring more frequently in women (23). However, the mortality rate was similar in men and women. In Finland, the mortality rate was increased in women and not men with acromegaly compared to the general population over a 20 -year period of observation (28). The female group was older, no dominant cause of death was identified and GH data was unavailable. A recent study of 718 acromegalic patients from Korea observed an increased risk of mortality in female but not male patients (20). Table 5 summarises studies that have

Table 5 Gender and standardised mortality in acromegaly.

\begin{tabular}{ll}
\hline Year & Reference \\
\cline { 1 - 1 } 1987 & Nabarro (154) \\
1998 & Abosch et al. (152) \\
2003 & Beauregard et al. (155) \\
2005 & Kauppinen-Makelin et al. (27) \\
2013 & Bogazzi et al. (156) \\
2014 & Mercado et al. (153) \\
2016 & Ritvonen et al. (28) \\
2018 & Esposito et al. (23) \\
\hline
\end{tabular}

\begin{tabular}{c}
\hline Study period \\
\hline $1963-1983$ \\
$1974-1992$ \\
$1970-1999$ \\
$1980-1999$ \\
$1999-2009$ \\
$1990-2010$ \\
$1980-1999$ \\
$1987-2013$
\end{tabular}

$\begin{array}{r}\hline \boldsymbol{n} \\ \hline 256 \\ 214 \\ 103 \\ 334 \\ 438 \\ 442 \\ 333 \\ 1089 \\ \hline\end{array}$

\begin{tabular}{ll}
\hline SMR \\
\hline 1.26 \\
1.28 \\
2.14 \\
1.16 \\
0.7 \\
0.76 \\
1.9 \\
2.79 \\
\hline
\end{tabular}

Gender comparison

$\mathrm{F}>\mathrm{M}(1.7$ vs 1.01)

$\mathrm{F}>\mathrm{M}(1.8$ vs 1.02$)$

$\mathrm{F}>\mathrm{M}(2.5$ vs 1.9)

$\mathrm{F}>\mathrm{M}(1.34$ vs 1.06)

$\mathrm{F}>\mathrm{M}(0.88$ vs 0.53$)$

$\mathrm{F}>\mathrm{M}(1.04$ vs 0.41)

$\mathrm{F}>\mathrm{M}(2.5$ vs 1.4)

$\mathrm{F} \sim \mathrm{M}(2.99$ vs 2.60$)$

F, female; M, male; SMR, standard mortality ratios. 
reported comparison between SMR in women and in men $(23,27,28,152,153,154,155,156)$.

In summary, mortality rate in uncontrolled acromegaly is increased but has fallen to that of the general population in parallel with attainment of disease control in both males and females. In studies where mortality rate is still increased, the risk is similar between the sexes, despite women having a higher risk of diabetes and hypertension. The collective evidence suggests no clear gender influence on mortality nor on beneficial effect of disease control.

\section{Summary}

Acromegaly is more prevalent in women than in men. There is a greater delay to diagnosis in female compared with male patients, despite experiencing symptoms for longer and seeing more doctors. QoL is more adversely affected in women than in men, predominantly due to mental health and sleep factors, and does not appear to improve as much after successful therapy. At diagnosis, women have lower IGF-I levels relative to GH status. Women present with larger, more invasive tumours in some but not all studies. The prevalence of diabetes and hypertension is increased, arguably affecting women more than men. Obstructive sleep apnoea prevalence is increased in acromegaly, with a male predominance reflecting that in the general population.

Women are equally responsive to SSAs but may require a higher dose of pegvisomant to achieve equivalent control compared to men. Surgical outcomes are similar except when tumour characteristics differ between male and female patients. The mortality rate is increased in uncontrolled acromegaly and has gradually fallen to that of the general population in both sexes through improved treatments and biochemical control. While women seem to have a higher risk of diabetes and hypertension, the improvement in life expectancy is not different between genders.

\section{Conclusion}

Gender has not been sufficiently considered as an important variable in the management of acromegaly such that a review necessitates extracting results from studies of varying quality and intent. Nevertheless, the information has allowed us to conclude from a literature survey of the epidemiology, management and treatment outcomes that acromegaly is more common in women, who also bear greater burden of disease. The biochemical profile in women consisting of relatively higher $\mathrm{GH}$, which causes insulin resistance, and lower IGF-I, which mediates anabolism, may contribute to a possible higher prevalence of hypertension, diabetes and to diagnostic delay. The mortality risk for men and women with acromegaly is increased but falls to that of the general population with treatments that cure or control disease. Although life expectancy can be restored in both sexes, the disease burden in women is greater from late diagnosis which prolongs suffering, potentially increasing the extent of complications compromising prognosis.

Gender does matter in the management of acromegaly. However, more research is required to determine the cause(s) of diagnostic delay and whether co-morbidities such as hypertension and diabetes are more prevalent in females with acromegaly. A programme of greater awareness for health practitioners and the community is required to remove gender disparity in the management of acromegaly.

\section{Declaration of interest}

$\mathrm{K} \mathrm{H}$ is an Associate Editor of European Journal of Endocrinology. He was not involved in the review or editorial process of this paper, on which he is listed as an author. The other authors have nothing to disclose.

\section{Funding}

This research did not receive any specific grant from any funding agency in the public, commercial or not-for-profit sector.

\section{References}

1 Hembree WC, Cohen-Kettenis PT, Gooren L, Hannema SE, Meyer WJ Murad MH, Rosenthal SM, Safer JD, Tangpricha V \& T'Sjoen GG. Endocrine treatment of gender-dysphoric/gender-incongruent persons: an Endocrine Society Clinical Practice Guideline. Endocrine Practice 201723 1437. (https://doi.org/10.4158/1934-240323.12.1437)

2 Klein SL \& Flanagan KL. Sex differences in immune responses. Nature Reviews: Immunology 201616 626-638. (https://doi.org/10.1038/ nri.2016.90)

3 Vroonen L, Daly AF \& Beckers A. Epidemiology and management challenges in prolactinomas. Neuroendocrinology 2019109 20-27. (https://doi.org/10.1159/000497746)

4 Heaney AP, Horwitz GA, Wang Z, Singson R \& Melmed S. Early involvement of estrogen-induced pituitary tumor transforming gene and fibroblast growth factor expression in prolactinoma pathogenesis. Nature Medicine 19995 1317-1321. (https://doi. org/10.1038/15275)

5 Burdman JA, Pauni M, Heredia Sereno GM \& Bordon AE. Estrogen receptors in human pituitary tumors. Hormone and Metabolic Research 200840 524-527. (https://doi.org/10.1055/s-2008-1065338)

6 Gao H, Xue Y, Cao L, Liu Q, Liu C, Shan X, Wang H, Gu Y \& Zhang Y. ESR1 and its antagonist fulvestrant in pituitary adenomas. Molecular and Cellular Endocrinology 2017443 32-41. (https://doi. org/10.1016/j.mce.2016.12.029) 
7 Gordon DA, Hill FM \& Ezrin C. Acromegaly: a review of 100 cases. Canadian Medical Association Journal 196287 1106-1109.

8 Alexander L, Appleton D, Hall R, Ross WM \& Wilkinson R. Epidemiology of acromegaly in the Newcastle region. Clinical Endocrinology 198012 71-79. (https://doi. org/10.1111/j.1365-2265.1980.tb03135.x)

9 Petrossians P, Daly AF, Natchev E, Maione L, Blijdorp K, SahnounFathallah M, Auriemma R, Diallo AM, Hulting AL, Ferone D et al. Acromegaly at diagnosis in 3173 patients from the Liege Acromegaly Survey (LAS) Database. Endocrine-Related Cancer 201724 505-518. (https://doi.org/10.1530/ERC-17-0253)

10 Meinhardt UJ \& Ho KK. Modulation of growth hormone action by sex steroids. Clinical Endocrinology 200665 413-422. (https://doi. org/10.1111/j.1365-2265.2006.02676.x)

11 Weissberger AJ \& Ho KK. Activation of the somatotropic axis by testosterone in adult males: evidence for the role of aromatization. Journal of Clinical Endocrinology and Metabolism 199376 1407-1412. (https://doi.org/10.1210/jcem.76.6.8501143)

12 Ho KY, Evans WS, Blizzard RM, Veldhuis JD, Merriam GR, Samojlik E, Furlanetto R, Rogol AD, Kaiser DL \& Thorner MO. Effects of sex and age on the 24-hour profile of growth hormone secretion in man: importance of endogenous estradiol concentrations. Journal of Clinical Endocrinology and Metabolism 198764 51-58. (https://doi. org/10.1210/jcem-64-1-51)

13 Burton T, Le Nestour E, Neary M \& Ludlam WH. Incidence and prevalence of acromegaly in a large US health plan database. Pituitary 201619 262-267. (https://doi.org/10.1007/s11102-015-0701-2)

14 Kwon O, Song YD, Kim SY, Lee EJ, Rare Disease Study Group, Research Committee. Nationwide survey of acromegaly in South Korea. Clinical Endocrinology 201378 577-585. (https://doi. org/10.1111/cen.12020)

15 Mestron A, Webb SM, Astorga R, Benito P, Catala M, Gaztambide S, Gomez JM, Halperin I, Lucas-Morante T, Moreno B et al. Epidemiology, clinical characteristics, outcome, morbidity and mortality in acromegaly based on the Spanish Acromegaly Registry (Registro Espanol de Acromegalia, REA). European Journal of Endocrinology 2004151 439-446. (https://doi.org/10.1530/ eje.0.1510439)

16 Gruppetta M, Mercieca C \& Vassallo J. Prevalence and incidence of pituitary adenomas: a population based study in Malta. Pituitary 201316 545-553. (https://doi.org/10.1007/s11102-012-0454-0)

17 Agustsson TT, Baldvinsdottir T, Jonasson JG, Olafsdottir E, Steinthorsdottir V, Sigurdsson G, Thorsson AV, Carroll PV, Korbonits M \& Benediktsson R. The epidemiology of pituitary adenomas in Iceland, 1955-2012: a nationwide population-based study. European Journal of Endocrinology 2015173 655-664. (https:// doi.org/10.1530/EJE-15-0189)

18 Bex M, Abs R, T'Sjoen G, Mockel J, Velkeniers B, Muermans K \& Maiter D. AcroBel--the Belgian registry on acromegaly: a survey of the 'real-life' outcome in 418 acromegalic subjects. European Journal of Endocrinology 2007157 399-409. (https://doi.org/10.1530/EJE-070358)

19 Tjornstrand A, Gunnarsson K, Evert M, Holmberg E, Ragnarsson O, Rosen T \& Filipsson Nystrom $\mathrm{H}$. The incidence rate of pituitary adenomas in western Sweden for the period 2001-2011. European Journal of Endocrinology 2014171 519-526. (https://doi.org/10.1530/ EJE-14-0144)

20 Park KH, Lee EJ, Seo GH \& Ku CR. Risk for acromegaly-related comorbidities by sex in Korean acromegaly. Journal of Clinical Endocrinology and Metabolism 2020 pii: dgz317 In press. (https://doi. org/10.1210/clinem/dgz317)

21 Arosio M, Reimondo G, Malchiodi E, Berchialla P, Borraccino A, De Marinis L, Pivonello R, Grottoli S, Losa M, Cannavo S et al. Predictors of morbidity and mortality in acromegaly: an Italian survey. European Journal of Endocrinology 2012167 189-198. (https://doi.org/10.1530/ EJE-12-0084)
22 Petersenn S, Buchfelder M, Gerbert B, Franz H, Quabbe HJ, Schulte HM, Grussendorf M, Reincke M \& Participants of the German Acromegaly Register. Age and sex as predictors of biochemical activity in acromegaly: analysis of 1485 patients from the German Acromegaly Register. Clinical Endocrinology 200971 400-405. (https://doi.org/10.1111/j.1365-2265.2009.03547.x)

23 Esposito D, Ragnarsson O, Granfeldt D, Marlow T, Johannsson G \& Olsson DS. Decreasing mortality and changes in treatment patterns in patients with acromegaly from a nationwide study. European Journal of Endocrinology 2018178 459-469. (https://doi.org/10.1530/ EJE-18-0015)

24 Maione L, Brue T, Beckers A, Delemer B, Petrossians P, BorsonChazot F, Chabre O, Francois P, Bertherat J, Cortet-Rudelli C et al. Changes in the management and comorbidities of acromegaly over three decades: the French Acromegaly Registry. European Journal of Endocrinology 2017176 645-655. (https://doi.org/10.1530/EJE-161064)

25 Vallette S, Ezzat S, Chik C, Ur E, Imran SA, Van Uum S, Rivera J, Caspar-Bell G \& Serri O. Emerging trends in the diagnosis and treatment of acromegaly in Canada. Clinical Endocrinology 201379 79-85. (https://doi.org/10.1111/cen.12112)

26 Park SH, Ku CR, Moon JH, Kim EH, Kim SH \& Lee EJ. Age- and sexspecific differences as predictors of surgical remission among patients with acromegaly. Journal of Clinical Endocrinology and Metabolism 2018103 909-916. (https://doi.org/10.1210/jc.2017-01844)

27 Kauppinen-Makelin R, Sane T, Reunanen A, Valimaki MJ, Niskanen L, Markkanen H, Loyttyniemi E, Ebeling T, Jaatinen P, Laine H et al. A nationwide survey of mortality in acromegaly. Journal of Clinical Endocrinology and Metabolism 200590 4081-4086. (https://doi. org/10.1210/jc.2004-1381)

28 Ritvonen E, Loyttyniemi E, Jaatinen P, Ebeling T, Moilanen L, Nuutila P, Kauppinen-Makelin R \& Schalin-Jantti C. Mortality in acromegaly: a 20-year follow-up study. Endocrine-Related Cancer 2016 23 469-480. (https://doi.org/10.1530/ERC-16-0106)

29 Colao A, Amato G, Pedroncelli AM, Baldelli R, Grottoli S, Gasco V, Petretta M, Carella C, Pagani G, Tambura G et al. Gender- and age-related differences in the endocrine parameters of acromegaly. Journal of Endocrinological Investigation 200225 532-538. (https://doi. org/10.1007/bf03345496)

30 Etxabe J, Gaztambide S, Latorre P \& Vazquez JA. Acromegaly: an epidemiological study. Journal of Endocrinological Investigation 1993 16 181-187. (https://doi.org/10.1007/BF03344942)

31 Granfeldt D, Bjorstad A, Tom M, Berthon A, Dinet J, Myrenfors P, Lesen E, Bjorholt I, Olsson DS \& Johannsson G. Gender differences in delays to diagnosis of acromegaly: data from the Swedish National Patient Register. Endocrine Abstracts 201856 158. (https://doi. org/10.1530/endoabs.56.P158)

32 Kreitschmann-Andermahr I, Siegel S, Kleist B, Kohlmann J, Starz D, Buslei R, Koltowska-Haggstrom M, Strasburger CJ \& Buchfelder M. Diagnosis and management of acromegaly: the patient's perspective. Pituitary 201619 268-276. (https://doi.org/10.1007/s11102-0150702-1)

33 Dal J, Feldt-Rasmussen U, Andersen M, Kristensen LØ, Laurberg P, Pedersen L, Dekkers OM, Sorensen HT \& Jorgensen JO. Acromegaly incidence, prevalence, complications and long-term prognosis: a nationwide cohort study. European Journal of Endocrinology 2016175 181-190. (https://doi.org/10.1530/EJE-16-0117)

34 Bondanelli M, Ambrosio MR, Margutti A, Franceschetti P, Zatelli MC \& degli Uberti EC. Activation of the somatotropic axis by testosterone in adult men: evidence for a role of hypothalamic growth hormone-releasing hormone. Neuroendocrinology 200377 380-387. (https://doi.org/10.1159/000071310)

35 Erfurth EM, Hagmar LE, Saaf M \& Hall K. Serum levels of insulinlike growth factor I and insulin-like growth factor-binding protein 1 correlate with serum free testosterone and sex hormone binding globulin levels in healthy young and middle-aged men. Clinical 
Endocrinology 199644 659-664. (https://doi.org/10.1046/j.13652265.1996.731552.x)

36 Pfeilschifter J, Scheidt-Nave C, Leidig-Bruckner G, Woitge HW, Blum WF, Wüster C, Haack D \& Ziegler R. Relationship between circulating insulin-like growth factor components and sex hormones in a population-based sample of 50- to 80-year-old men and women. Journal of Clinical Endocrinology and Metabolism 199681 2534-2540. (https://doi.org/10.1210/jcem.81.7.8675573)

37 Hobbs CJ, Plymate SR, Rosen CJ \& Adler RA. Testosterone administration increases insulin-like growth factor-I levels in normal men. Journal of Clinical Endocrinology and Metabolism $1993 \mathbf{7 7}$ 776-779. (https://doi.org/10.1210/jcem.77.3.7690364)

38 Hagenfeldt Y, Linde K, Sjoberg HE, Zumkeller W \& Arver S. Testosterone increases serum 1,25-dihydroxyvitamin D and insulin-like growth factor-I in hypogonadal men. International Journal of Andrology 199215 93-102. (https://doi. org/10.1111/j.1365-2605.1992.tb01118.x)

39 Gibney J, Wolthers T, Johannsson G, Umpleby AM \& Ho KK. Growth hormone and testosterone interact positively to enhance protein and energy metabolism in hypopituitary men. American Journal of Physiology: Endocrinology and Metabolism 2005289 E266-E271. (https://doi.org/10.1152/ajpendo.00483.2004)

40 Freda PU. Pitfalls in the biochemical assessment of acromegaly. Pituitary 20036 135-140. (https://doi.org/10.1023/ b:pitu.0000011174.79946.10)

41 Frantz AG \& Rabkin MT. Effects of estrogen and sex difference on secretion of human growth hormone. Journal of Clinical Endocrinology and Metabolism 196525 1470-1480. (https://doi.org/10.1210/jcem25-11-1470)

42 Tanaka S, Fukuda I, Hizuka N \& Takano K. Gender differences in serum GH and IGF-I levels and the GH response to dynamic tests in patients with acromegaly. Endocrine Journal 201057 477-483. (https://doi.org/10.1507/endocrj.k09e-342)

43 Parkinson C, Renehan AG, Ryder WD, O'Dwyer ST, Shalet SM \& Trainer PJ. Gender and age influence the relationship between serum GH and IGF-I in patients with acromegaly. Clinical Endocrinology 200257 59-64. (https://doi.org/10.1046/j.1365-2265.2002.01560.x)

44 Leistner SM, Klotsche J, Dimopoulou C, Athanasoulia AP, RoemmlerZehrer J, Pieper L, Schopohl J, Wittchen HU, Stalla GK, Fulda S et al. Reduced sleep quality and depression associate with decreased quality of life in patients with pituitary adenomas. European Journal of Endocrinology 2015172 733-743. (https://doi.org/10.1530/EJE-140941)

45 Webb SM, Crespo I, Santos A, Resmini E, Aulinas A \& Valassi E. MANAGEMENT of ENDOCRINE DISEASE: quality of life tools for the management of pituitary disease. European Journal of Endocrinology 2017177 R13-R26. (https://doi.org/10.1530/EJE-17-0041)

46 Webb SM, Badia X, Surinach NL \& Spanish AcroQol Study Group. Validity and clinical applicability of the acromegaly quality of life questionnaire, AcroQoL: a 6-month prospective study. European Journal of Endocrinology 2006155 269-277. (https://doi.org/10.1530/ eje.1.02214)

47 Vandeva S, Yaneva M, Natchev E, Elenkova A, Kalinov K \& Zacharieva S. Disease control and treatment modalities have impact on quality of life in acromegaly evaluated by Acromegaly Quality of Life (AcroQoL) Questionnaire. Endocrine 201549 774-782. (https:// doi.org/10.1007/s12020-014-0521-6)

48 Fujio S, Arimura H, Hirano H, Habu M, Bohara M, Moinuddin FM, Kinoshita Y \& Arita K. Changes in quality of life in patients with acromegaly after surgical remission - A prospective study using SF-36 questionnaire. Endocrine Journal 201764 27-38. (https://doi. org/10.1507/endocrj.EJ16-0182)

49 Psaras T, Honegger J, Gallwitz B \& Milian M. Are there genderspecific differences concerning quality of life in treated acromegalic patients? Experimental and Clinical Endocrinology and Diabetes 2011 119 300-305. (https://doi.org/10.1055/s-0030-1267912)
50 van der Klaauw AA, Kars M, Biermasz NR, Roelfsema F, Dekkers OM, Corssmit EP, van Aken MO, Havekes B, Pereira AM, Pijl H et al. Disease-specific impairments in quality of life during long-term follow-up of patients with different pituitary adenomas. Clinical Endocrinology 200869 775-784. (https://doi.org/10.1111/j.13652265.2008.03288.x)

51 Biermasz NR, van Thiel SW, Pereira AM, Hoftijzer HC, van Hemert AM, Smit JW, Romijn JA \& Roelfsema F. Decreased quality of life in patients with acromegaly despite long-term cure of growth hormone excess. Journal of Clinical Endocrinology and Metabolism 2004 89 5369-5376. (https://doi.org/10.1210/jc.2004-0669)

52 Anagnostis P, Efstathiadou ZA, Charizopoulou M, Selalmatzidou D, Karathanasi E, Poulasouchidou M \& Kita M. Psychological profile and quality of life in patients with acromegaly in Greece. Is there any difference with other chronic diseases? Endocrine 201447 564-571. (https://doi.org/10.1007/s12020-014-0166-5)

53 T'Sjoen G, Bex M, Maiter D, Velkeniers B \& Abs R. Health-related quality of life in acromegalic subjects: data from AcroBel, the Belgian registry on acromegaly. European Journal of Endocrinology 2007157 411-417. (https://doi.org/10.1530/EJE-07-0356)

54 Rowles SV, Prieto L, Badia X, Shalet SM, Webb SM \& Trainer PJ. Quality of life (QOL) in patients with acromegaly is severely impaired: use of a novel measure of QOL: acromegaly quality of life questionnaire. Journal of Clinical Endocrinology and Metabolism 2005 90 3337-3341. (https://doi.org/10.1210/jc.2004-1565)

55 Kepicoglu H, Hatipoglu E, Bulut I, Darici E, Hizli N \& Kadioglu P. Impact of treatment satisfaction on quality of life of patients with acromegaly. Pituitary 201417 557-563. (https://doi.org/10.1007/ s11102-013-0544-7)

56 Tseng FY, Chen ST, Chen JF, Huang TS, Lin JD, Wang PW, HueyHerng Sheu W, Chang TC \& Acromegaly Registry Study Group. Correlations of clinical parameters with quality of life in patients with acromegaly: Taiwan Acromegaly Registry. Journal of the Formosan Medical Association 2019118 1488-1493.

57 Boero L, Manavela M, Gomez Rosso L, Insua C, Berardi V, Fornari MC $\&$ Brites F. Alterations in biomarkers of cardiovascular disease (CVD) in active acromegaly. Clinical Endocrinology 200970 88-95. (https:// doi.org/10.1111/j.1365-2265.2008.03323.x)

58 Cannavo S, Almoto B, Cavalli G, Squadrito S, Romanello G, Vigo MT, Fiumara F, Benvenga S \& Trimarchi F. Acromegaly and coronary disease: an integrated evaluation of conventional coronary risk factors and coronary calcifications detected by computed tomography. Journal of Clinical Endocrinology and Metabolism 200691 3766-3772. (https://doi.org/10.1210/ jc.2005-2857)

59 Berg C, Petersenn S, Lahner H, Herrmann BL, Buchfelder M, Droste M, Stalla GK, Strasburger CJ, Roggenbuck U, Lehmann N et al. Cardiovascular risk factors in patients with uncontrolled and long-term acromegaly: comparison with matched data from the general population and the effect of disease control. Journal of Clinical Endocrinology and Metabolism 201095 3648-3656. (https:// doi.org/10.1210/jc.2009-2570)

60 Gonzalez B, Vargas G, de Los Monteros ALE, Mendoza V \& Mercado M. Persistence of diabetes and hypertension after multimodal treatment of acromegaly. Journal of Clinical Endocrinology and Metabolism 2018103 2369-2375. (https://doi.org/10.1210/jc.2018-00325)

61 Holdaway IM, Bolland MJ \& Gamble GD. A meta-analysis of the effect of lowering serum levels of GH and IGF-I on mortality in acromegaly. European Journal of Endocrinology 2008159 89-95. (https://doi.org/10.1530/EJE-08-0267)

62 Schmermund A, Mohlenkamp S, Stang A, Gronemeyer D, Seibel R, Hirche H, Mann K, Siffert W, Lauterbach K, Siegrist J et al. Assessment of clinically silent atherosclerotic disease and established and novel risk factors for predicting myocardial infarction and cardiac death in healthy middle-aged subjects: rationale and design of the Heinz Nixdorf RECALL Study. Risk factors, evaluation of coronary calcium 
and lifestyle. American Heart Journal 2002144 212-218. (https://doi. org $/ 10.1067 / \mathrm{mhj} .2002 .123579$ )

63 Portocarrero-Ortiz LA, Vergara-Lopez A, Vidrio-Velazquez M, UribeDiaz AM, Garcia-Dominguez A, Reza-Albarran AA, Cuevas-Ramos D, Melgar V, Talavera J, Rivera-Hernandez AJ et al. The Mexican Acromegaly Registry: clinical and biochemical characteristics at diagnosis and therapeutic outcomes. Journal of Clinical Endocrinology and Metabolism 2016101 3997-4004. (https://doi.org/10.1210/jc.2016-1937)

64 Gillis EE \& Sullivan JC. Sex differences in hypertension: recent advances. Hypertension 201668 1322-1327. (https://doi.org/10.1161/ HYPERTENSIONAHA.116.06602)

65 Colao A, Ferone D, Marzullo P \& Lombardi G. Systemic complications of acromegaly: epidemiology, pathogenesis, and management. Endocrine Reviews 200425 102-152. (https://doi. org/10.1210/er.2002-0022)

66 Ciresi A, Amato MC, Pivonello R, Nazzari E, Grasso LF, Minuto F, Ferone D, Colao A \& Giordano C. The metabolic profile in active acromegaly is gender-specific. Journal of Clinical Endocrinology and Metabolism 201398 E51-E59. (https://doi.org/10.1210/jc.2012-2896)

67 Pivonello R, Auriemma RS, Grasso LF, Pivonello C, Simeoli C, Patalano R, Galdiero M \& Colao A. Complications of acromegaly: cardiovascular, respiratory and metabolic comorbidities. Pituitary 201720 46-62. (https://doi.org/10.1007/s11102-017-0797-7)

68 Senaratna CV, Perret JL, Lodge CJ, Lowe AJ, Campbell BE, Matheson MC, Hamilton GS \& Dharmage SC. Prevalence of obstructive sleep apnea in the general population: a systematic review. Sleep Medicine Reviews 201734 70-81. (https://doi. org/10.1016/j.smrv.2016.07.002)

69 Roemmler J, Gutt B, Fischer R, Vay S, Wiesmeth A, Bidlingmaier M, Schopohl J \& Angstwurm M. Elevated incidence of sleep apnoea in acromegaly-correlation to disease activity. Sleep and Breathing 2012 16 1247-1253. (https://doi.org/10.1007/s11325-011-0641-7)

70 Sze L, Schmid C, Bloch KE, Bernays R \& Brandle M. Effect of transsphenoidal surgery on sleep apnoea in acromegaly. European Journal of Endocrinology 2007156 321-329. (https://doi.org/10.1530/ eje.1.02340)

71 van Haute FR, Taboada GF, Correa LL, Lima GA, Fontes R, Riello AP, Dominici M \& Gadelha MR. Prevalence of sleep apnea and metabolic abnormalities in patients with acromegaly and analysis of cephalometric parameters by magnetic resonance imaging. European Journal of Endocrinology 2008158 459-465. (https://doi.org/10.1530/ EJE-07-0753)

72 Akkoyunlu ME, Ilhan MM, Bayram M, Tasan E, Yakar F, Ozcelik HK, Karakose F \& Kart L. Does hormonal control obviate positive airway pressure therapy in acromegaly with sleep-disordered breathing? Respiratory Medicine 2013107 1803-1809. (https://doi.org/10.1016/j. rmed.2013.08.043)

73 Annamalai AK, Webb A, Kandasamy N, Elkhawad M, Moir S, Khan F, Maki-Petaja K, Gayton EL, Strey CH, O'Toole S et al. A comprehensive study of clinical, biochemical, radiological, vascular, cardiac, and sleep parameters in an unselected cohort of patients with acromegaly undergoing presurgical somatostatin receptor ligand therapy. Journal of Clinical Endocrinology and Metabolism 201398 1040-1050. (https:// doi.org/10.1210/jc.2012-3072)

74 Attal P \& Chanson P. Endocrine aspects of obstructive sleep apnea. Journal of Clinical Endocrinology and Metabolism 201095 483-495. (https://doi.org/10.1210/jc.2009-1912)

75 Castellani C, Francia G, Dalle Carbonare L, Ferrari M, Viva E, Cerini R, Zaccarella A, Trevisiol L \& Davi MV. Morphological study of upper airways and long-term follow-up of obstructive sleep apnea syndrome in acromegalic patients. Endocrine 201651 308-316. (https://doi.org/10.1007/s12020-015-0659-x)

76 Chemla D, Attal P, Maione L, Veyer AS, Mroue G, Baud D, Salenave S, Kamenicky P, Bobin S \& Chanson P. Impact of successful treatment of acromegaly on overnight heart rate variability and sleep apnea.
Journal of Clinical Endocrinology and Metabolism 201499 2925-2931. (https://doi.org/10.1210/jc.2013-4288)

77 Davi MV, Dalle Carbonare L, Giustina A, Ferrari M, Frigo A, Lo Cascio V \& Francia G. Sleep apnoea syndrome is highly prevalent in acromegaly and only partially reversible after biochemical control of the disease. European Journal of Endocrinology 2008159 533-540. (https://doi.org/10.1530/EJE-08-0442)

78 Dostalova S, Sonka K, Smahel Z, Weiss V, Marek J \& Horinek D. Craniofacial abnormalities and their relevance for sleep apnoea syndrome aetiopathogenesis in acromegaly. European Journal of Endocrinology 2001144 491-497. (https://doi.org/10.1530/ eje.0.1440491)

79 Hernandez-Gordillo D, Ortega-Gomez Mdel Mdel R, Galicia-Polo L, Castorena-Maldonado A, Vergara-Lopez A, Guillen-Gonzalez MÁ $\&$ Torre-Bouscoulet L. Sleep apnea in patients with acromegaly. Frequency, characterization and positive pressure titration. Open Respiratory Medicine Journal 20126 28-33. (https://doi.org/10.2174/18 74306401206010028)

80 Wennberg A, Lorusso R, Dassie F, Benavides-Varela S, Parolin M, De Carlo E, Fallo F, Mioni R, Vettor R, Semenza C et al. Sleep disorders and cognitive dysfunction in acromegaly. Endocrine 201966 634-641. (https://doi.org/10.1007/s12020-019-02061-1)

81 Weiss V, Sonka K, Pretl M, Dostalova S, Klozar J, Rambousek P, Marek J \& Haas T. Prevalence of the sleep apnea syndrome in acromegaly population. Journal of Endocrinological Investigation 2000 23 515-519. (https://doi.org/10.1007/BF03343767)

82 Turan O, Akinci B, Ikiz AO, Itil O, Oztura I, Ada E, Akdeniz B, Yener S, Kaya M, Gedik A et al. Airway and sleep disorders in patients with acromegaly. Clinical Respiratory Journal 201812 1003-1010. (https://doi.org/10.1111/crj.12618)

83 Jenkins PJ, Mukherjee A \& Shalet SM. Does growth hormone cause cancer? Clinical Endocrinology 200664 115-121. (https://doi. org/10.1111/j.1365-2265.2005.02404.x)

84 Dal J, Leisner MZ, Hermansen K, Farkas DK, Bengtsen M, Kistorp C, Nielsen EH, Andersen M, Feldt-Rasmussen U, Dekkers OM et al. Cancer incidence in patients with acromegaly: a cohort study and metaanalysis of the literature. Journal of Clinical Endocrinology and Metabolism 2018103 2182-2188. (https://doi.org/10.1210/jc.2017-02457)

85 Mian C, Ceccato F, Barollo S, Watutantrige-Fernando S, Albiger N, Regazzo D, de Lazzari P, Pennelli G, Rotondi S, Nacamulli D et al. AHR over-expression in papillary thyroid carcinoma: clinical and molecular assessments in a series of Italian acromegalic patients with a long-term follow-up. PLoS ONE 20149 e101560. (https://doi. org/10.1371/journal.pone.0101560)

86 Gullu BE, Celik O, Gazioglu N \& Kadioglu P. Thyroid cancer is the most common cancer associated with acromegaly. Pituitary 201013 242-248. (https://doi.org/10.1007/s11102-010-0224-9)

87 Kim HK, Lee JS, Park MH, Cho JS, Yoon JH, Kim SJ \& Kang HC. Tumorigenesis of papillary thyroid cancer is not BRAF-dependent in patients with acromegaly. PLoS ONE 20149 e110241. (https://doi. org/10.1371/journal.pone.0110241)

88 Wolinski K, Stangierski A, Dyrda K, Nowicka K, Pelka M, Iqbal A, Car A, Lazizi M, Bednarek N, Czarnywojtek A et al. Risk of malignant neoplasms in acromegaly: a case-control study. Journal of Endocrinological Investigation 201740 319-322. (https://doi. org/10.1007/s40618-016-0565-y)

89 Rokkas T, Pistiolas D, Sechopoulos P, Margantinis G \& Koukoulis G. Risk of colorectal neoplasm in patients with acromegaly: a metaanalysis. World Journal of Gastroenterology 200814 3484-3489. (https://doi.org/10.3748/wjg.14.3484)

90 Dagdelen S, Cinar N \& Erbas T. Increased thyroid cancer risk in acromegaly. Pituitary 201417 299-306. (https://doi.org/10.1007/ s11102-013-0501-5)

91 Dalle Carbonare L, Micheletti V, Cosaro E, Valenti MT, Mottes M, Francia G \& Davi MV. Bone histomorphometry in acromegaly 
patients with fragility vertebral fractures. Pituitary 201821 56-64. (https://doi.org/10.1007/s11102-017-0847-1)

92 Giustina A, Mazziotti G \& Canalis E. Growth hormone, insulin-like growth factors, and the skeleton. Endocrine Reviews 200829 535-559. (https://doi.org/10.1210/er.2007-0036)

93 Mazziotti G, Biagioli E, Maffezzoni F, Spinello M, Serra V, Maroldi R, Floriani I \& Giustina A. Bone turnover, bone mineral density, and fracture risk in acromegaly: a meta-analysis. Journal of Clinical Endocrinology and Metabolism 2015100 384-394. (https://doi. org/10.1210/jc.2014-2937)

94 Seeman E, Wahner HW, Offord KP, Kumar R, Johnson WJ \& Riggs BL. Differential effects of endocrine dysfunction on the axial and the appendicular skeleton. Journal of Clinical Investigation 198269 1302-1309. (https://doi.org/10.1172/jci110570)

95 Kaji H, Sugimoto T, Nakaoka D, Okimura Y, Kaji H, Abe H \& Chihara K. Bone metabolism and body composition in Japanese patients with active acromegaly. Clinical Endocrinology 200155 175-181. (https://doi.org/10.1046/j.1365-2265.2001.01280.x)

96 Ezzat S, Melmed S, Endres D, Eyre DR \& Singer FR. Biochemical assessment of bone formation and resorption in acromegaly. Journal of Clinical Endocrinology and Metabolism 199376 1452-1457. (https:// doi.org/10.1210/jcem.76.6.8501150)

97 Hubsch P, Kotzmann H, Svoboda T, Kainberger FM, Bankier A \& Seidl G. [Bone density of the lumbar spine and femur in acromegaly]. Der Radiologe 199333 457-461.

98 Kayath MJ \& Vieira JG. Osteopenia occurs in a minority of patients with acromegaly and is predominant in the spine. Osteoporosis International 19977 226-230. (https://doi.org/10.1007/bf01622293)

99 Valassi E, Crespo I, Malouf J, Llauger J, Aulinas A, Marin AM, Biagetti B \& Webb SM. Reduction of trabecular and cortical volumetric bone mineral density at the proximal femur in patients with acromegaly. European Journal of Endocrinology $2016 \mathbf{1 7 4}$ 107-114. (https://doi.org/10.1530/EJE-15-0931)

100 Claessen KM, Kroon HM, Pereira AM, Appelman-Dijkstra NM, Verstegen MJ, Kloppenburg M, Hamdy NA \& Biermasz NR. Progression of vertebral fractures despite long-term biochemical control of acromegaly: a prospective follow-up study. Journal of Clinical Endocrinology and Metabolism 201398 4808-4815. (https:// doi.org/10.1210/jc.2013-2695)

101 Wassenaar MJ, Biermasz NR, Hamdy NA, Zillikens MC, van Meurs JB, Rivadeneira F, Hofman A, Uitterlinden AG, Stokkel MP, Roelfsema F et al. High prevalence of vertebral fractures despite normal bone mineral density in patients with long-term controlled acromegaly. European Journal of Endocrinology 2011164 475-483. (https://doi. org/10.1530/EJE-10-1005)

102 Mazziotti G, Bianchi A, Bonadonna S, Cimino V, Patelli I, Fusco A, Pontecorvi A, De Marinis L \& Giustina A. Prevalence of vertebral fractures in men with acromegaly. Journal of Clinical Endocrinology and Metabolism 200893 4649-4655. (https://doi.org/10.1210/ jc.2008-0791)

103 Mazziotti G, Bianchi A, Porcelli T, Mormando M, Maffezzoni F, Cristiano A, Giampietro A, De Marinis L \& Giustina A. Vertebral fractures in patients with acromegaly: a 3-year prospective study. Journal of Clinical Endocrinology and Metabolism 201398 3402-3410. (https://doi.org/10.1210/jc.2013-1460)

104 Bollerslev J, Heck A \& Olarescu NC. MANAGEMENT of ENDOCRINE DISEASE: individualized management of acromegaly. European Journal of Endocrinology 2019181 R57-R71. (https://doi.org/10.1530/ EJE-19-0124)

105 Fernandez-Rodriguez E, Casanueva FF \& Bernabeu I. Update on prognostic factors in acromegaly: is a risk score possible? Pituitary 201518 431-440. (https://doi.org/10.1007/s11102-014-0574-9)

106 Jane JA Jr, Starke RM, Elzoghby MA, Reames DL, Payne SC, Thorner MO, Marshall JC, Laws ER Jr \& Vance ML. Endoscopic transsphenoidal surgery for acromegaly: remission using modern criteria, complications, and predictors of outcome. Journal of Clinical
Endocrinology and Metabolism 201196 2732-2740. (https://doi. org/10.1210/jc.2011-0554)

107 Antunes X, Ventura N, Camilo GB, Wildemberg LE, Guasti A, Pereira PJM, Camacho AHS, Chimelli L, Niemeyer P, Gadelha MR et al. Predictors of surgical outcome and early criteria of remission in acromegaly. Endocrine 201860 415-422. (https://doi.org/10.1007/ s12020-018-1590-8)

108 Hazer DB, Isik S, Berker D, Guler S, Gurlek A, Yucel T \& Berker M. Treatment of acromegaly by endoscopic transsphenoidal surgery: surgical experience in 214 cases and cure rates according to current consensus criteria. Journal of Neurosurgery 2013119 1467-1477. (https://doi.org/10.3171/2013.8.JNS13224)

109 Babu H, Ortega A, Nuno M, Dehghan A, Schweitzer A, Bonert HV, Carmichael JD, Cooper O, Melmed S \& Mamelak AN. Longterm endocrine outcomes following endoscopic endonasal transsphenoidal surgery for acromegaly and associated prognostic factors. Neurosurgery 201781 357-366. (https://doi.org/10.1093/ neuros/nyx020)

110 Yildirim AE, Sahinoglu M, Divanlioglu D, Alagoz F, Gurcay AG, Daglioglu E, Okay HO \& Belen AD. Endoscopic endonasal transsphenoidal treatment for acromegaly: 2010 consensus criteria for remission and predictors of outcomes. Turkish Neurosurgery 2014 24 906-912. (https://doi.org/10.5137/1019-5149.JTN.11288-14.1)

111 Hofstetter CP, Mannaa RH, Mubita L, Anand VK, Kennedy JW, Dehdashti AR \& Schwartz TH. Endoscopic endonasal transsphenoidal surgery for growth hormone-secreting pituitary adenomas. Neurosurgical Focus 201029 E6. (https://doi.org/10.3171/2010.7.FO CUS10173)

112 Campbell PG, Kenning E, Andrews DW, Yadla S, Rosen M \& Evans JJ. Outcomes after a purely endoscopic transsphenoidal resection of growth hormone-secreting pituitary adenomas. Neurosurgical Focus 201029 E5. (https://doi.org/10.3171/2010.7.FOCUS10153)

113 Gondim JA, Almeida JP, de Albuquerque LA, Gomes E, Schops M $\&$ Ferraz T. Pure endoscopic transsphenoidal surgery for treatment of acromegaly: results of 67 cases treated in a pituitary center. Neurosurgical Focus 201029 E7. (https://doi.org/10.3171/2010.7.FO CUS10167)

114 Carmichael JD, Bonert VS, Nuno M, Ly D \& Melmed S. Acromegaly clinical trial methodology impact on reported biochemical efficacy rates of somatostatin receptor ligand treatments: a meta-analysis. Journal of Clinical Endocrinology and Metabolism 201499 1825-1833. (https://doi.org/10.1210/jc.2013-3757)

115 Melmed S, Bronstein MD, Chanson P, Klibanski A, Casanueva FF, Wass JAH, Strasburger CJ, Luger A, Clemmons DR \& Giustina A. A consensus statement on acromegaly therapeutic outcomes. Nature Reviews: Endocrinology 201814 552-561. (https://doi.org/10.1038/ s41574-018-0058-5)

116 Fleseriu M. Clinical efficacy and safety results for dose escalation of somatostatin receptor ligands in patients with acromegaly: a literature review. Pituitary 201114 184-193. (https://doi.org/10.1007/ s11102-010-0282-z)

117 Colao A, Bronstein MD, Freda P, Gu F, Shen CC, Gadelha M, Fleseriu M, van der Lely AJ, Farrall AJ, Hermosillo Resendiz K et al. Pasireotide versus octreotide in acromegaly: a head-to-head superiority study. Journal of Clinical Endocrinology and Metabolism 201499 791-799. (https://doi.org/10.1210/jc.2013-2480)

118 Cuevas-Ramos D \& Fleseriu M. Somatostatin receptor ligands and resistance to treatment in pituitary adenomas. Journal of Molecular Endocrinology 201452 R223-R240. (https://doi.org/10.1530/JME-140011)

119 Melmed S, Cook D, Schopohl J, Goth MI, Lam KSL \& Marek J. Rapid and sustained reduction of serum growth hormone and insulin-like growth factor-1 in patients with acromegaly receiving lanreotide autogel therapy: a randomized, placebo-controlled, multicenter study with a 52 week open extension. Pituitary 201013 18-28. (https://doi. org/10.1007/s11102-009-0191-1) 
120 Lucas T, Astorga R, Catala M \& Spanish Multicentre Lanreotide Study Group. Preoperative lanreotide treatment for GH-secreting pituitary adenomas: effect on tumour volume and predictive factors of significant tumour shrinkage. Clinical Endocrinology $2003 \mathbf{5 8}$ 471-481. (https://doi.org/10.1046/j.1365-2265.2003.01741.x)

121 Caron P, Beckers A, Cullen DR, Goth MI, Gutt B, Laurberg P, Pico AM, Valimaki M \& Zgliczynski W. Efficacy of the new long-acting formulation of lanreotide (lanreotide autogel) in the management of acromegaly. Journal of Clinical Endocrinology and Metabolism 200287 99-104. (https://doi.org/10.1210/jcem.87.1.8153)

122 Chanson P, Borson-Chazot F, Kuhn JM, Blumberg J, Maisonobe P \& Delemer B. Delemer B \& lanreotide Acromegaly Study G. Control of IGF-I levels with titrated dosing of lanreotide autogel over 48 weeks in patients with acromegaly. Clinical Endocrinology 200869 299-305. (https://doi.org/10.1111/j.13652265.2008.03208.x)

123 Giustina A, Mazziotti G, Cannavo S, Castello R, Arnaldi G, Bugari G, Cozzi R, Ferone D, Formenti AM, Gatti E et al. High-dose and high-frequency lanreotide autogel in acromegaly: a randomized, multicenter study. Journal of Clinical Endocrinology and Metabolism 2017102 2454-2464. (https://doi.org/10.1210/jc.2017-00142)

124 Baldelli R, Colao A, Razzore P, Jaffrain-Rea ML, Marzullo P, Ciccarelli E, Ferretti E, Ferone D, Gaia D, Camanni F et al. Two-year follow-up of acromegalic patients treated with slow release lanreotide (30 mg). Journal of Clinical Endocrinology and Metabolism 200085 4099-4103. (https://doi.org/10.1210/jcem.85.11.6948)

125 Verhelst JA, Pedroncelli AM, Abs R, Montini M, Vandeweghe MV, Albani G, Maiter D, Pagani MD, Legros JJ, Gianola D et al. Slowrelease lanreotide in the treatment of acromegaly: a study in 66 patients. European Journal of Endocrinology 2000143 577-584. (https://doi.org/10.1530/eje.0.1430577)

126 Caron PJ, Bevan JS, Petersenn S, Flanagan D, Tabarin A, Prévost G, Maisonobe P, Clermont A \& Investigators P. Tumor shrinkage with lanreotide autogel $120 \mathrm{mg}$ as primary therapy in acromegaly: results of a prospective multicenter clinical trial. Journal of Clinical Endocrinology and Metabolism 201499 1282-1290. (https://doi. org/10.1210/jc.2013-3318)

127 Lombardi G, Minuto F, Tamburrano G, Ambrosio MR, Arnaldi G, Arosio M, Chiarini V, Cozzi R, Grottoli S, Mantero F et al. Efficacy of the new long-acting formulation of lanreotide (lanreotide autogel) in somatostatin analogue-naive patients with acromegaly. Journal of Endocrinological Investigation 200932 202-209. (https://doi. org/10.1007/BF03346453)

128 Vance ML \& Harris AG. Long-term treatment of 189 acromegalic patients with the somatostatin analog octreotide. Results of the International Multicenter Acromegaly Study Group. Archives of Internal Medicine 1991151 1573-1578.

129 Cozzi R, Attanasio R, Montini M, Pagani G, Lasio G, Lodrini S, Barausse M, Albizzi M, Dallabonzana D \& Pedroncelli AM. Four-year treatment with octreotide-long-acting repeatable in 110 acromegalic patients: predictive value of short-term results? Journal of Clinical Endocrinology and Metabolism 200388 3090-3098. (https://doi. org/10.1210/jc.2003-030110)

130 Lancranjan I \& Atkinson AB. Results of a European multicentre study with Sandostatin LAR in acromegalic patients. Sandostatin LAR Group. Pituitary 19991 105-114. (https://doi. org/10.1023/a:1009980404404)

131 Newman CB, Melmed S, George A, Torigian D, Duhaney M, Snyder P, Young W, Klibanski A, Molitch ME, Gagel R et al. Octreotide as primary therapy for acromegaly. Journal of Clinical Endocrinology and Metabolism 199883 3034-3040. (https://doi.org/10.1210/ jcem.83.9.5109)

132 Tutuncu Y, Berker D, Isik S, Ozuguz U, Akbaba G, Kucukler FK, Aydin Y \& Guler S. Comparison of octreotide LAR and lanreotide autogel as post-operative medical treatment in acromegaly. Pituitary 201215 398-404. (https://doi.org/10.1007/s11102-011-0335-y)
133 Mercado M, Borges F, Bouterfa H, Chang TC, Chervin A, Farrall AJ, Patocs A, Petersenn S, Podoba J, Safari M et al. A prospective, multicentre study to investigate the efficacy, safety and tolerability of octreotide LAR (long-acting repeatable octreotide) in the primary therapy of patients with acromegaly. Clinical Endocrinology $2007 \mathbf{6 6}$ 859-868. (https://doi.org/10.1111/j.1365-2265.2007.02825.x)

134 Fleseriu M, Rusch E, Geer EB \& Investigators AS. Safety and tolerability of pasireotide long-acting release in acromegaly-results from the acromegaly, open-label, multicenter, safety monitoring program for treating patients who have a need to receive medical therapy (ACCESS) study. Endocrine 201755 247-255. (https://doi. org/10.1007/s12020-016-1182-4)

135 Bronstein MD, Fleseriu M, Neggers S, Colao A, Sheppard M, Gu F, Shen CC, Gadelha M, Farrall AJ, Hermosillo Resendiz K et al. Switching patients with acromegaly from octreotide to pasireotide improves biochemical control: crossover extension to a randomized, double-blind, phase III study. BMC Endocrine Disorders 20161616. (https://doi.org/10.1186/s12902-016-0096-8)

136 Sheppard M, Bronstein MD, Freda P, Serri O, De Marinis L, Naves L, Rozhinskaya L, Hermosillo Resendiz K, Ruffin M, Chen Y et al. Pasireotide LAR maintains inhibition of GH and IGF-1 in patients with acromegaly for up to 25 months: results from the blinded extension phase of a randomized, double-blind, multicenter, phase III study. Pituitary 201518 385-394. (https://doi.org/10.1007/s11102014-0585-6)

137 Petersenn S, Schopohl J, Barkan A, Mohideen P, Colao A, Abs R, Buchelt A, Ho YY, Hu K, Farrall AJ et al. Pasireotide (SOM230) demonstrates efficacy and safety in patients with acromegaly: a randomized, multicenter, phase II trial. Journal of Clinical Endocrinology and Metabolism 201095 2781-2789. (https://doi. org/10.1210/jc.2009-2272)

138 Muhammad A, Coopmans EC, Delhanty PJD, Dallenga AHG, Haitsma IK, Janssen JAMJL, van der Lely AJ \& Neggers SJCMM. Efficacy and safety of switching to pasireotide in acromegaly patients controlled with pegvisomant and somatostatin analogues: PAPE extension study. European Journal of Endocrinology 2018179 269-277. (https://doi.org/10.1530/EJE-18-0353)

139 Gadelha MR, Bronstein MD, Brue T, Coculescu M, Fleseriu M, Guitelman M, Pronin V, Raverot G, Shimon I, Lievre KK et al. Pasireotide versus continued treatment with octreotide or lanreotide in patients with inadequately controlled acromegaly (PAOLA): a randomised, phase 3 trial. Lancet: Diabetes and Endocrinology 20142 875-884. (https://doi.org/10.1016/S22138587(14)70169-X)

140 Parkinson C, Burman P, Messig M \& Trainer PJ. Gender, body weight, disease activity, and previous radiotherapy influence the response to pegvisomant. Journal of Clinical Endocrinology and Metabolism 200792 190-195. (https://doi.org/10.1210/jc.2006-1412)

141 Marazuela M, Lucas T, Alvarez-Escola C, Puig-Domingo M, de la Torre NG, de Miguel-Novoa P, Duran-Hervada A, Manzanares R, Luque-Ramirez M, Halperin I et al. Long-term treatment of acromegalic patients resistant to somatostatin analogues with the GH receptor antagonist pegvisomant: its efficacy in relation to gender and previous radiotherapy. European Journal of Endocrinology 2009 160 535-542. (https://doi.org/10.1530/EJE-08-0705)

142 Franck SE, Korevaar TIM, Petrossians P, Daly AF, Chanson P, JaffrainRea ML, Brue T, Stalla GK, Carvalho D, Colao A et al. A multivariable prediction model for pegvisomant dosing: monotherapy and in combination with long-acting somatostatin analogues. European Journal of Endocrinology 2017176 421-431. (https://doi.org/10.1530/ EJE-16-0956)

143 Abu Dabrh AM, Asi N, Farah WH, Mohammed K, Wang Z, Farah MH, Prokop LJ, Katznelson L \& Murad MH. Radiotherapy versus radiosurgery in treating patients with acromegaly: a systematic review and meta-analysis. Endocrine Practice 201521 943-956. (https://doi.org/10.4158/EP14574.OR) 
144 Ding D, Mehta GU, Patibandla MR, Lee CC, Liscak R, Kano H, Pai FY, Kosak M, Sisterson ND, Martinez-Alvarez R et al. Stereotactic radiosurgery for acromegaly: an international multicenter retrospective cohort study. Neurosurgery 201984 717-725. (https:// doi.org/10.1093/neuros/nyy178)

145 Jenkins PJ, Bates P, Carson MN, Stewart PM \& Wass JA. Conventional pituitary irradiation is effective in lowering serum growth hormone and insulin-like growth factor-I in patients with acromegaly. Journal of Clinical Endocrinology and Metabolism 200691 1239-1245. (https:// doi.org/10.1210/jc.2005-1616)

146 Lee CC, Vance ML, Xu Z, Yen CP, Schlesinger D, Dodson B \& Sheehan J. Stereotactic radiosurgery for acromegaly. Journal of Clinical Endocrinology and Metabolism 201499 1273-1281. (https://doi. org/10.1210/jc.2013-3743)

147 Franzin A, Spatola G, Losa M, Picozzi P \& Mortini P. Results of gamma knife radiosurgery in acromegaly. International Journal of Endocrinology 20122012 342034. (https://doi. org/10.1155/2012/342034)

148 Barrande G, Pittino-Lungo M, Coste J, Ponvert D, Bertagna X, Luton JP $\&$ Bertherat J. Hormonal and metabolic effects of radiotherapy in acromegaly: long-term results in 128 patients followed in a single center. Journal of Clinical Endocrinology and Metabolism $2000 \mathbf{8 5}$ 3779-3785. (https://doi.org/10.1210/jcem.85.10.6870)

149 Poon TL, Leung SC, Poon CY \& Yu CP. Predictors of outcome following gamma knife surgery for acromegaly. Journal of Neurosurgery Supplement 149-152 2010113 149-152. (https://doi. org/10.3171/2010.7.GKS10933)
150 Wright AD, Hill DM, Lowy C \& Fraser TR. Mortality in acromegaly. Quarterly Journal of Medicine 197039 1-16.

151 Nabarro JD. Management of acromegaly. Journal of Clinical Pathology. Supplement 19767 62-67. (https://doi.org/10.1136/jcp.s1-7.1.62)

152 Abosch A, Tyrrell JB, Lamborn KR, Hannegan LT, Applebury CB \& Wilson CB. Transsphenoidal microsurgery for growth hormonesecreting pituitary adenomas: initial outcome and long-term results. Journal of Clinical Endocrinology and Metabolism 199883 3411-3418. (https://doi.org/10.1210/jcem.83.10.5111)

153 Mercado M, Gonzalez B, Vargas G, Ramirez C, de los Monteros AL, Sosa E, Jervis P, Roldan P, Mendoza V, Lopez-Felix B et al. Successful mortality reduction and control of comorbidities in patients with acromegaly followed at a highly specialized multidisciplinary clinic. Journal of Clinical Endocrinology and Metabolism 201499 4438-4446. (https://doi.org/10.1210/jc.2014-2670)

154 Nabarro JD. Acromegaly. Clinical Endocrinology 198726 481-512. (https://doi.org/10.1111/j.1365-2265.1987.tb00805.x)

155 Beauregard C, Truong U, Hardy J \& Serri O. Long-term outcome and mortality after transsphenoidal adenomectomy for acromegaly. Clinical Endocrinology 200358 86-91. (https://doi.org/10.1046/ j.1365-2265.2003.01679.x)

156 Bogazzi F, Colao A, Rossi G, Lombardi M, Urbani C, Sardella C, Iannelli A, Scattina I, Manetti L, Del Sarto S et al. Comparison of the effects of primary somatostatin analogue therapy and pituitary adenomectomy on survival in patients with acromegaly: a retrospective cohort study. European Journal of Endocrinology 2013169 367-376. (https://doi.org/10.1530/EJE-13-0166)

Received 14 December 2019

Revised version received 5 February 2020

Accepted 17 February 2020 